7

\title{
A SOCIOLOGICAL SURVEY OF THE SOCIO-ECONOMIC DILEMMA OF THE AGED IN LESS DEVELOPED COUNTRIES
}

\author{
Akhabue A. Okharedia
}

\begin{abstract}
This paper attempts to highlight the current socio-economic dilimma of the aged in less developed countries with special reference to Africa. The identified problems include role conflict and the effects of Western industrialization process on the various traditional institutions. For example, the introduction of popular franchise by the Western society has adversely affected the traditional political system based on gerontocracy. In the same vein, the constitutional procedure has also reduced the wisdom and power of the aged in Africa. Possible solutions are offered on how to eliminate the above problems so as to improve the socio-economic status of the aged in Africa.
\end{abstract}

\section{INTRODUCTION}

Unfortunately, not much research has been carried out on ageing in developing countries. The reason often advanced by scholars is that the number of aged people in developing countries is not as high as in the developed countries. This assertion is not true when we consider the statistical figures available in world population. In the same vein, if we consider the socio-economic situation of the aged in developing 
Countries, it is self-evident that ageing population in developing countries deserves more attention than in the developed countries.

According to the U.S. Bureau Bulletin of the Census and Database on Ageing published in 1988, the world's total population is growing at a rate of 1.7 per cent per year. The population aged 55 and above is increasing by 2.2 per cent per year; and the number of persons aged 65 and over, is rising by 2.8 per cent annually. The bulletin shows further that every month, the net balance of the World's older population (55 years and over) increases by 1.2 million persons. More than 80 per cent of this monthly increase, almost 1 million persons occur in developing countries. The bulletin further illustrates that there are now some 370 million people aged 55 and over living in developing countries, representing 58 per cent of the world total in this age category. Additionally, it is also shown that over the next three decades, the regional distribution of older population will change considerably; by the year 2020, the proportion in developing countries is projected to rise to 72 per cent, with the absolute figure outnumbering their counterparts in the developed countries by 13 per cent in 1988 (159 million versus 140 million, respectively). By the year 2020, the population aged 65 and over in developing countries is expected to surpass 470 million, which will be more than double the number in developed countries. With regard to developing countries, Table 1 below shows the percentage of the total population in the various regions.

Table 1 Percentage of Total Populations in Older Age Groups: 1988 - 2020

\begin{tabular}{|l|l|l|l|l|l|}
\hline Region & Year & $\begin{array}{l}55 \text { Years } \\
\text { Over }\end{array}$ & 65 Years \& Over & 75 Years \& Over \\
\hline Asia & 1988 & 10.4 & 4.5 & 1.3 \\
& 2005 & 12.8 & 6.1 & 2.0 \\
& 2020 & 17.5 & 8.3 & 2.7 \\
\hline Africa & 1988 & 7.0 & 2.9 & 0.7 \\
& 2005 & 7.2 & 3.1 & 0.8 \\
& 2020 & 8.2 & 3.6 & 1.0 \\
\hline Latin America & 1988 & 9.4 & 4.4 & 1.4 \\
& 2005 & 11.4 & 5.5 & 2.0 \\
& 2020 & 15.8 & 7.5 & 2.7 \\
\hline Caribbean & 1988 & 11.7 & 6.1 & 2.2 \\
& 2005 & 13.7 & 6.8 & 2.6 \\
& 2020 & 18.7 & 9.0 & 3.3 \\
\hline
\end{tabular}

Source: U.S. Bureau of the Census, Centre for International Research, International Database on Ageing 1988. 
Among the various regions showed above, the Caribbean has the highest proportion (11.7 per cent) of population aged 55 and over. Asia and Latin America have more than 10 per cent and 9 per cent, respectively, and Africa as a whole has 7 per cent. It was also clearly stated in this bulletin that, although Africa has the lowest proportion of older populations at the moment, its growth rate for ages 55 and over will be the highest among world regions during the next decade.

\section{THEORETICAL CONSIDERATION}

For us to understand the concept of ageing as it is analyzed in this paper, it is perhaps necessary for us to briefly discuss its theoretical underpinning that is relevant to this research.

The Disengagement Theory: This social psychological theory of ageing was propounded by Elaine Cumming and William Henry (1961) in their book, Growing Old. Their study, which comprised 275 men and women between the ages, of 50 and 90, was based on the observed fact that ageing involves a gradual relinquishment of social roles and a decrease in social interaction. Cumming and Henry argue that both the individual and society prepare in advance for the ultimate disengagement (death) through a gradual, mutually beneficial process during which the individual and society withdraw from one another. Their statement is as follows: "In our theory, ageing is an inevitable mutual withdrawal or disengagement, resulting in decreased interaction between the ageing person and others in the social system he or she belongs to. The process may be initiated by the individual or by others in the situation. The ageing person may withdraw more markedly from some classes of people while remaining relatively close to others. His withdrawal may be accompanied from the onset by an increased pre-occupation with himself; certain institutions in society may make this withdrawal easy for him. When the ageing process is complete, the equilibrium which existed in middle life between the individual and the society will give way to a new equilibrium characterized by a greater distance and an altered type of relationship".

According to Cumming and Henry, disengagement is inevitable because death is inevitable. Old people prepare for their deaths by divesting themselves of social relationships and social functions. Society also encourages its members to do this so that their death will not be disruptive to its equilibrium. This, of course, buttresses the fact that disengagement is a two-way process whereby the individual withdraws from the society and the society withdraws from the individual. They argue further that when the process is complete, the individual has shifted from being pre-occupied with society to self-pre-occupation. 
However, a critique of this theory by Arnold Rose shows that the disengagement process is not inevitable. According to Rose, the lack of involvement in later life may be a continuation of a life-long pattern for some people. Many people never disengage and continue to be socially involved all their lives. Rose never saw disengagement as something beneficial to the individual. Empirical studies show that the elderly who are engaged tend to be in most cases, the happiest and to have the greatest life satisfaction. Rose concluded this analysis by pointing out clearly that many trends in our society serve to counteract the forces leading to disengagement of the elderly. These trends include:

i. advances in medical care and services, which have led to better health and increased vigour for older people;

ii. more economic security for the elderly through pension plans, social security and annuities.

iii. development of social movements among older people to raise their prestige and to increase their privileges;

iv. the expansion of activities and hobbies for the elderly which may afford them more roles and options.

The Activity Theory: The emphasis here is on the continuation of role performance. This is in contrast with the disengagement theory which emphasizes withdrawal from roles. With regards to this activity theory, the central idea is that when roles are lost, such as in retirement and widowhood, the individual is expected to find substitutes. This theory clearly states that: "The older person who ages optimally is the person who stays active and who manages to resist the shrinkage of his social world. He maintains the activities of middle age as long as possible and then finds substitutes for work when he is forced to retire; substitutes for friends and loved ones whom he loses by death".

This theory holds that society withdraws from the ageing person, but this is against the person's will or desire. It recommends further that, to minimize this withdrawal, the person must try to be alive, keep busy and stay young.

Modernization Theory: The central idea of modernization theory is that the processes that cause societies to evolve from rural and agrarian social and economic systems to urban and industrial ones also cause change in the positions that older people occupy in the society and the esteem accorded the aged. This perspective of change is often considered to be for the worse. 


\section{Annals of The Social Science Council of Nigeria, No. 7, January-December, 1995}

The work of Simmons (1945) is probably one of the first to address the issue of modernization's effect on the elderly. His study is on a cross-cultural analysis of 71 societies. Simmons concludes in this study that in relatively stable agricultural societies, the aged usually occupy positions of favour and power, owing mainly to the concept of seniority rights. But when the rate of change increases, Simmons said, the aged lose their advantaged status. Unfortunately, he did not specify how or why this is so.

With regard to Cottrell's analysis (1942), he views modernizations as a result of the growing use of fossil fuel and technology to increase human productivity. He argues further that the most significant aspect of the historical shift from agrarian to high energy industrial forms of production is its effect on the organization of society. He states that agrarian societies revolve around the village, which itself is a collection of families. The power of elderly men, and occasionally elderly women, in the agrarian system develop from their positions as heads of families, which allow them to be part and parcel of the council of elders that controls members of the community administratively. The rules and laws made to guide the community are principally based on traditional norms. Heads of families make decisions in all realms of life which include economic, political, religious and social aspects. But, with modernization, the cordial relationship between human effort and the volume of goods produced weakened, hi view of the fact that production depends less on land and more on technology, decision-making power shifted from landowners to relatively fewer factory owners and merchants, which eroded the power of family patriarchs. Additionally, with the expansion of science which has grown beyond the capacity of any one human to know it all, the value of the elders as keepers of knowledge has diminished.

The empirical study of Sicher (1978:108 - 1.12) concludes that, in order for the new egalitarian type of society to emerge, the traditional hierarchical type had to be undercut. In the course of this egalitarian process the aged who were usually in control of traditional societies came directly under attack by those forces who wanted to change the system. It was neither their capabilities nor a lack of them that caused the aged to lose their roles and prestigious positions, but rather the fact that they were now seen as symbols of an outdated social order.

The above explanations contribute greatly to the main reasons why the aged lost their identity in the industrialized society. Having discussed briefly some of the gerontological theories about the aged, an attempt will now be made to look at the status of the aged in Africa. 


\section{THE EFFECT OF SOCIO-ECONOMIC FACTORS ON POPULATION GROWTH IN LDCs}

In the introductory part of this paper, it was shown that, although Africa has the lowest proportion of older population at the moment, its growth rate for ages 55 and over will be the highest among world regions during the next decade. There is a general dictum that there is a very high rate of population growth in Africa. For a thorough understanding of the problems facing the aged people in Africa, it is perhaps necessary for us to understand the socio-economic factors that have contributed to an increase in population in the region. In the same vein, a fuller understanding of the traditional status of the aged in Africa would also enable us to understand the genesis of the problems.

In recent times, however and with the improvement in health care knowledge, housing, sanitation and balanced diet, as well as the prophylactic clinical, the rate of mortality has drastically reduced and life expectancy of individuals has increased (Rosenmayr 1991).

The second factor that has led to increase in population is that African children are often seen by their parents as insurance against parents' old age problems (Masamba ma Mpolo 1984). Thirdly, children are seen as a source of labour pool to be used by parents in agricultural activity within the household (Todaro 1994). The fourth factor is a sociological one based on the author's personal observation among some communities in Nigeria. Among the Edo community, for instance, there is a traditional belief that if a man has all his children from the same woman, they (children) are all considered to be only one child, hi an attempt, therefore, for a man to show that he has many children, he is bound to be polygamous and this often results in a large number of children belonging to one man, thus increasing the population of the community.

The fifth factor could be attributed to early marriage and the little period people in LDCs spend at school (Todaro 1977). And lastly, it could also be argued that the various African governments have not taken serious measures to check population explosion.

\section{THE STATUS OF THE AGED IN AFRICA}

At this juncture, we may now look at the traditional status of the aged in Africa. The work of Frances Cox with Ndungu Mberia (1979) on ageing has contributed greatly to our understanding of the status of the aged in Africa. Cox and Mberia argue brilliantly that, traditionally, elderly people in Africa were respected and fully integrated into community life. The elderly people were never seen as a burden. 


\section{Annals of The Social Science Council of Nigeria, No. 7, January-December, 1995}

Older persons played a special role in educating and socializing the young and this was clearly seen among the Akikuyu of Kenya. It was also pointed out in the study of the aged by Masamba ma Mpolo (1984) that when the elderly were no longer able to work on fields, forest and rivers they remained in the village, weaving baskets, making clothing for the entire family and caring for small children, while their parents were at work. He argues further that in this category, the elderly closely followed the physical, emotional and ethical development of the young. For example, grandparents maintained open relationships with their grandchildren, whom they taught appropriate ways of interacting with their parents and others in the community and with whom they shared humour and relaxation. The elderly are seen as living libraries, as reservoirs of knowledge and wisdom, passing on to the young the history and culture of the people. They introduced younger generations to different trades and professions, such as commerce, weaving, fishing, and story telling. Significantly, the important area of family education, such as parenting and sexuality, was primarily the arena of selected and gifted elders. Among the Xhosa people of South Africa, the initiation of boys into manhood is the responsibility of the male elders, in the case of young girls, they learnt about womanhood and parental obligations from elderly women. Elders are responsible for the continuity of family linkages and health of the entire extended family. The extended family freed its members from the stress of loneliness and poverty. The stability of family ties including the incorporation of special needs, such as care of the disabled, were the concern of the whole community under the guidance of its elders.

\section{PROBLEMS FACING THE AGED}

Having analyzed the traditional status of the elderly in Africa, we can now discuss the common problems facing the elderly in Africa and other developing countries. One of the major problems is the breakdown of family ties. This had been found to be true in both urban and rural areas (Ekpenyong, Peil and Oyeneye 1986, Masamba ma Mpolo 1984; Apt, N.A. 1985; Beer 1976; Hampson 1982).

According to Masamba ma Mpolo (1984); migration by the young people to the town has virtually left many old people without emotional and financial support from families. Those most affected by broken family ties are those without any other means of income. Various pension scheme benefits are not available to non-wage earners in many developing countries. The non-availability of pension schemes to those elderly people who never experienced wage employment keeps them in perpetual poverty in developing countries. These problems could be solved by the respective governments by making everybody pensionable, provided they paid tax during their working life time. 
The second common problem of the elderly in developing countries is the problem of nutrition. According to C.K. Brown (1985), in his study of the elderly in the Accra region of Ghana, 67.0 per cent were able to eat exactly what they wanted, 25.0 per cent ate twice a day and 2.8 per cent ate once a day. He also showed clearly that most of the food eaten (75.0 per cent), however, was made up of carbohydrates and starchy foods and short of protein and other body-building foods. Majority never ate a balanced diet. In addition to this, the deterioration in their physiognomy and loss of teeth, in some cases, rendered some of them unable to eat hard food substances.

The third common problem of the elderly in developing countries is the problem of malnutrition. A survey of the aged in Bangladesh which was conducted by M. Ibrahim in 1985 shows that 85 per cent of older workers subsist beneath the minimum requirements of 2000 calories daily. According to Tout, a study of 230 elderly people of Jamaica revealed protein energy malnutrition in 24 per cent of men and 18 per cent of women. Triceps skin folds values were less than 60 per cent of standard. Thiamine and vitamin $\mathrm{C}$ were particularly deficient. A study of the elderly in Peru shows that the elderly are the main sufferers from sub nutrition, with a diet seriously lacking in necessary vitamins (Tout 1989). It was also found that this leads to another vicious cycle whereby constant malnutrition renders an old person depressed or even acutely mentally confused, so that the person becomes indifferent to feeding requirements, or forgets to provide food, or is unable to judge the daily balance of nutrition and prepare the daily menu, hi a number of African countries the malnutrition problem is even more extreme. In countries like Ethiopia and Somalia, the malnutrition problem has affected a very large number of the elderly population who have no means of having a balanced diet. The malnutrition problem is a serious issue and needs immediate attention of the World Health Organization.

Furthermore, from the author's personal observation in most African rural communities, lack of modern social services like pipe- borne water, medical facilities and old people's centres are also crucial problems facing the aged in developing countries. Health services in many developing countries have tended to focus on mothers and small children and on prevention and control of communicable diseases. The health care of the aged is not given priority, and is often left for the extended family, whereas caring for elderly family members is becoming increasingly difficult to do. In our study of the aged in Nigeria, one of our aged respondents had this to say: "You see, I am now waiting to die. I don't have any relation or any institution to care for me. My future life is very bleak and hopeless. I am now useless and I think it would be much better if I die".

In Nigeria one's research on the health problems of the elderly shows that malaria fever is the commonest illness and this is clearly shown in Table 1. In this particular 
research, the rationale for the study was to find out the various types of illness facing the elderly in Edo State of Nigeria.

\section{RESEARCH METHODOLOGY}

The field work was conducted in 1994 in five towns of Edo State, namely: Ubiaja, Benin, Igarra, Udo and Auchi.

Ubiaja: This is an old town and the former headquarters of Ishan division. Most of the inhabitants are farmers, businessmen and civil servants.

Benin: This is also an old town which is densely populated and with many business centres and a University.

Igarra: This is a fairly populated town with numerous hills. Udo: A small rural community about three miles from Ubiaja. Auchi This is a fairly big town with a polytechnic College.

The respondents of the study were made up of 200 selected individuals aged 60 years and above. A purposive sampling technique was used in selecting the respondents, hi each of the towns those aged 60 years and above were known and since they were scattered over the towns, it was therefore more convenient for me to use purposive sampling techniques in selecting the respondents. The main research technique used for the fieldwork was the interview schedule which covered the following questions and characteristics: personal data such as age, religion, education, marital status, training and apprenticeship, their commonest illness, past and present employment, community participation, leisure and amusement, reflections about old age, social contacts and suggestions for improving life in old age. The schedule was administered with the help of two research assistants. On the average, an interview lasted about one and half hours.

In addition to this interview, the library research method was used to collect and examine available background and community data from census and other documents on ageing in other less developed countries.

\section{RESEARCH FINDINGS}

This research shows that 90 per cent of the respondents agreed that the elderly no longer play an active part in family matters in Nigeria as they used to do. They made 
it clear to us that with the existence of Customary Courts and Magistrate Courts family, members prefer to refer their disputes to the various courts rather than the family council of elders. It is on very rare occasions that civil cases are referred to the elders. All criminal cases are no longer referred to the council of elders. In view of this, elders are no longer seen as living libraries, reservoirs of knowledge and wisdom as they used to be.

With regard to the type of illness facing the elderly in Edo State of Nigeria, as clearly shown in (Table 2), 156 out of 200 respondents agreed that their commonest illness is malaria fever. This is a problem for the elderly whose reserve of energy is consumed by malaria. From the hospital records, deaths due to such illness are not uncommon. The anopheles mosquitoes, the main transmitters of malaria, is a debilitating feature of our tropical climate. The commonest treatment available for the elderly is the use of traditional medicine (Agbo and Dongoyaro) made locally by the people. The fansidar, chloroquine and other modern malaria drugs are too expensive for the people.

\section{Table 2 Type of Illnesses facing the Elderly in Edo State of Nigeria}

\begin{tabular}{|c|c|c|c|c|c|c|c|}
\hline \multirow{2}{*}{\multicolumn{3}{|c|}{$\begin{array}{l}\text { Name of Towns Number of } \\
\text { Respondents in Nigeria }\end{array}$}} & & \multicolumn{4}{|c|}{ Type of Illness Complained by Each of the } \\
\hline & & & \multicolumn{3}{|c|}{ Interviewed in Each Town } & \multicolumn{2}{|c|}{ Back- Tooth } \\
\hline $\begin{array}{l}\text { Protein } \\
\text { ness }\end{array}$ & Eye & $\begin{array}{l}\text { Deaf- } \\
\text { fy }\end{array}$ & Malaria & Others ache & pain & Deficiency & problems \\
\hline Ubiaja & 40 & 212 & & 35 & & & \\
\hline Benin & 60 & 64 & & 10 & & 40 & \\
\hline Igarra & 35 & 24 & & 1 & 2 & 26 & \\
\hline Udo & 0 & 1 & & & & 17 & \\
\hline Auchi & 45 & 31 & & & 38 & $3 *$ & \\
\hline Total & 200 & 11 & 11 & 13 & 2 & 156 & \\
\hline
\end{tabular}

From the table we could also see that eye disease is also a problem facing the elderly in Nigeria. It affects both male and female equally. Unfortunately, there is no standard traditional medicine which could be used by the people as in the case of malaria 
fever. Most of the local healers do not have permanent solutions to the eye problem. The local hospitals are quite few and there is also the problem of physical distance in getting to the hospitals. As a matter of fact, many of the aged are not covered by any health insurance scheme and because of this, they are also not interested hi going to the hospitals because they cannot afford the required fees.

In addition to the above problem is the high degree of illiteracy as far as Western education is concerned among the aged in Nigeria. About 60 per cent of the respondents interviewed in this research have lived without opportunities for literacy/ formal education. The literacy rate, as far as Western education is concerned, is very low compared with that of younger generations. The well-being of older persons is often linked to their educational experiences earlier in life. Formal educational attainment greatly enhances economic prospects and permits younger persons to prepare for the economics of old age. It was observed in this research that lack of Western education has adversely affected the aged when it comes to using banking facilities, hi Nigeria, the official language in the bank is English and this foreign language creates problems for the aged in Nigeria and other developing countries from full utilization of the available banking services, and other social services. This problem could be eased by using the indigenous language of the people in the banking sector. I would not recommend that adult education centres should be established to improve literacy level in Western education because many of the aged can no longer stand the rigour of learning anything, least of all, foreign languages.

\section{THE DILEMMA OF THE AGED IN AFRICA}

In Africa today, the aged are experiencing the problem of role conflicts. According to Tout, the aged in Africa are the head of their respective families. In view of this, they are expected to play the traditional roles to the family and the community at large. Most of these traditional roles involve making of ritual sacrifice to their dead ancestors, and the worship of rivers, stones, trees and other traditional images, hi the same vein, these aged people in the family belong to Western churches which forbid them from worshipping the above objects. If the aged refuse to perform those traditional rites, they will be disowned by the family and the community. On the other hand, if the church is aware that they participate in ritual sacrifices they will no longer be accepted in their various churches, therefore, the aged are bound to experience role conflict, that is, in their traditional responsibility to the family and in their obligation as members of the church.

The aged are in a state of dilemma. Unfortunately, they cannot strike a compromise between the two different beliefs. Further research is needed in this perspective, so 
as to be able to provide valid solutions to this problem of role conflict. The work of Fadipe (1970) also discusses the effects of social change on the aged. Fadipe argues that the introduction of popular franchise has reduced the hold of the traditional political systems based on gerontocracy. Consequently, there is a decline in the public role of the elders. Ceremonial functions associated with cultural activities are still retained. However, there is a relative loss of prestige and power and this has brought to the elderly both economic and emotional problems. The introduction of constitutional rule by British and French governments in their respective colonies in Africa succeeded in reducing the influence, the wisdom and power of the aged in Africa. The traditional role of the aged in setting disputes has been reduced to a single legal action that can be taken by individuals in courts, through a constitutional procedure. The aged are no longer respected for their wisdom and knowledge as it was in the traditional African society. Many of them are emotionally worried about this and wish that their traditional status is preserved.

Other important changes concern the establishment of the British and French rule which has affected the functions of the aged, as war chiefs, and chiefs, and others who were considered important in purely traditional systems of government but whose functions have no place in the new governmental set-up. Many of the aged in their community today have been left with virtually no function.

It has also been observed that the socialization of children in the family is no longer left for the aged members alone. Schools and other bureaucratic organizations have now taken over some of the basic functions of the aged. In the traditional African society, the aged who could no longer work had always occupied themselves by caring for the young ones at home. This also made them busy and at the same time not to be very lonely. But bureaucratic organizations have taken over this function of caring for the young ones, the aged are now often seen to be very lonely and this also creates a psychological problem for them.

Early anthropologists who studied African society, especially scholars like Lucy Mair (1977) and Bradbury, R. E. (1973) had earlier argued that the aged in Africa have been the custodian of traditional medicine used in curing various types of illness. The prescription and sale of this medicine has been a regular source of income for the aged. But with the invention of modern medicine, the market value of the traditional medicine has been drastically reduced and with the indoctrination of the Western culture that anything foreign is superior to locally produced ones, the local medicine has suffered a predictable fate. This has also made the aged in African villages not only to be unemployed but to live without sufficient financial resources. This problem could be solved by government encouraging the production of traditional medicine through moral suasion. 
The spread of Western industrialization also created problems for the aged in Africa. Traditionally, African elders were able to manufacture their cooking pots, cooling system and their own clothes. But with the invention of refrigerators, textile machines and other electrical equipment, the elders have been forced to abandon their traditional occupation of providing the implement. The aged abandoned this occupation because they could no longer compete favourably with the imported items. The loss of this occupation has contributed to the financial hardship of the aged in Africa.

However, attempts are now being made in Africa to solve the above problems. A recent research study of the aged in Kenya by Cox and Mberia (1979), M. J. Menya (1985) and information obtained from Kenya Central Bureau of Statistics confirm that the Kenyan Government has established the Fundumi Rural Life Extension Society which is active in promoting dairy farming projects in which older people can participate, as well as in developing schemes that utilize their traditional pot-making skills. For some years the Kenyan clay pottery industry had been neglected owing to the availability of cheap tin and plastic articles. It is interesting to note that the aged in Kenya still retained skills in the making of clay pots. Fundumi helped to develop improved types of clay 'jikos' (traditional pottery ovens) with which older people were able to revive the almost forgotten craft, with obvious economic advantage to the elderly section of the population. Records from the social welfare department in Burundi also shows that the government has also made efforts to establish the "Eglise Protestants Episcopale". This is an organization whose principal focus is to distribute food, soap and other necessary household materials to the aged in the society. It is also seen as an organization for an on going monitoring of 125 widows, and at the same time keeping a discrete watch on their health and social conditions.

In Ghana, research on the elderly by Apt, and Twamasi (1981), Brown C. L. (1985) and other statistical records from the health department shows that the Government of Ghana has made efforts in recent times to improve the health services of the aged. For example, efforts have been made by the Government to renovate Asankrangwa Hospital which has been in a state of disuse for many years. The aim of this project is to see to the possibility of using the hospital as a base for a domiciliary programme for the older inhabitants in an inaccessible area and with many small scattered communities.lt is also hoped that the hospital would serve as an initial base from which to investigate other initiatives for working with the elderly of Ghana as well as inducing local communities and organizations to develop their own specific schemes of aid to the elderly. 
In the case of Zimbabwe, Hampson (1982) and records from the welfare departments confirm that the Harare School of Social Work has demonstrated an outstanding commitment to the welfare of the aged in recent times. In 1986, it held its second "workshop" which gathered together social workers concerned with the aged both in Zimbabwe itself and in surrounding countries, including Zambia.. Generally speaking, in most African countries, very little efforts have been made by the respective governments to solve the many problems of the aged.

\section{CONCLUSIONS AND RECOMMENDATIONS}

Unfortunately, at the international level, not much effort has been made with regard to the problem of the aged in Africa. Observation shows that there is no international organization like the Economic Commission for Africa to co-ordinate all the activities of the respective governments with regard to the aged people on the continent. The only international organization being formed in recent times is the African Society of Gerontology which, of course, is still in embryonic stage. The African Society of Gerontology has not been able to take off on a full scale basically because of financial problems. In order to solve this problem of finance, African governments should think seriously about contributing a reasonable amount to the organization, in the same way they contribute regularly to the Organization of African Unity (OAU). As an alternative, if the financial burden is too much for member states to bear, then they could incorporate the African Society of Gerontology as one of the organs of the Organization for African Unity (OAU).

The United Nations can also make a direct financial contribution to African Society of Gerontology. This would enable the young organization to locate its bearing and carry out its main objectives which includes among other things:

i. to encourage African Governments to take into account the problems of ageing when elaborating their national policies, programmes and development.

ii. to make recommendations to member states with the view to promoting in Africa the implementation of international plan of action on ageing.

iii. to promote the implementation of the African plan of action on ageing.

iv. to develop organic relations with different international scientific or social institutions involved in research and training in the field of ageing. 
Given that the current economic problems in many developing nations hinder individual savings, the extended family should be encouraged by the government to support the aged in their communities. The government could do this by giving more tax reduction to individuals supporting elderly parents hi their families. Special assistance which includes finance, clothing and medical should be made available to families who support bedridden older or disabled parents, hi addition to this, "old parents' allowance" should be provided to adults who are taking care of elderly relatives. If such social policy is well planned and monitored, this could facilitate not only the care of elderly parents but help to maintain the extended family relationships.

With regards to the health problems of the elderly, the expansion of geriatric medicine is an urgent necessity, hi addition to this, the impact of traditional cultural beliefs on older persons should be included in medical and paramedical school curricula. On the issue of loneliness among the aged in our communities, it is pertinent to say that those aged people who are still fit to work be employed in those institutions where they can continue to help hi the socialization of the young ones and where they can also contribute to the socio-economic development of the state. However, such employment should be based on locatio conductio operis (work acceptance contract).

Finally, it can hardly be over-emphasized that we need to conduct more research on how best we can improve the health care, nutrition and better living environment for the elderly in our communities.

\section{REFERENCES}

Anzola-Perrez, E.: "Ageing in Latin America and Caribbean" Pan-American Health Organization (PAHO).

Apt, N. A. (1985): Ageing in Ghana. Legon: University of Ghana.

Apt, N. A. \& Twamasi, P. A.: "Education and the Elderly. The Ghanian Experience" Legion: Unpublished manuscript: University of Ghana Department of Sociology,

Arnold, M. Rose, (1965): "Current Theoretical Issues in Social Gerontology", hi Arnold M. Rose and Warren A. Peterson, F.A. Davis (eds.)Older People and Their Social World. Philadelphia.

Beer, C'. (1976V. The Politics of Peasant Groups in Western Nigeria. Ibadan: Ibadan University Press. 
Brown, C. K. (1985): "Research Findings in Ghana: A Survey on the Elderly in Accra Region". African Gerontology No. 4, November.

Bradbury, R.E.( 1973): Benin Studies. Oxford: Oxford University Press.

Cottrell, Fred (1960A): "Government Functions and the Politics of Age" Clark Tibbitts (ed) Handbook of Social Gerontology. Chicago: University of Chicago Press.

Cottrell, Leonard (1942): "Adjustment of the Individual to his Age and Sex Roles" American Sociological Review, 1

Cox, F. \& Ndung'u Mberia (1979): Ageing in Changing Village Society: A Kenyan Experience. Washington D.C.: The International Federation on Ageing.

Elaine Cumming \& William E. Henry (1961): Growing Old. New York: Basic Books. Ekpenyong, S.; O. Y. Oyeneye; \& M. Peil, (1986): Reports on Study of Elderly Nigerians. Centre of West African Study, University of Birmingham.

Fischer, David H. (1978): Growing Old in America. Expanded Edition. New York: Oxford University Press.

Fadipe, N. A. (1970): The Sociology of the Yoruba In F. O. Okediji and O. O. Okediji (eds.), University of Ibadan Press, Ibadan.

Hampson, J. (1982): Old Age: A Study of Ageing in Zimbabwe. Gweru and Harare: Mambo.

Ibrahim, M. (1985): Tradition and Modern Development in Bangladesh Society. Dhaka: Bangledeshi Association for the Aged.

Masamba, M., A. Mpolo (1984): Old Persons and Their Families in Changing Village Society: A Perspective from Zaire. Geneva, Switzerland: International Federation Ageing and the World Council of Churches

Menya, M. J. (1985): "Medical and Social Welfare of the Elderly in Kenya". African Gerontology, No. 4, November.

Mair Lucy, (1977): African Kingdoms. Oxford: Oxford University Press.

Rosenmary, L. (1990): The Position of the Old in Tribal Society. (Report from a Field Study in West Africa. The Sandoz Lectures), pp. 25-51, London: Academic Press.

Rosenmary, L. (1991): "Ageing in Mali, "A Seminar Paper Presented at the Department of Sociology, University of Vienna.

Simmons, L. H. (1945): The Roles of the Aged in Primitive Society. New Haven: Yale University Press.

Tout, K. (1989): Ageing in Developing Countries. Oxford: Oxford University Press. Todaro, Michael (1994): Economic Development (5th Edition). Lagos: Longman. 